ACTA MYCOLOGICA

Vol. 45 (1): 67-72

2010
Dedicated to Professor Barbara Gumińska

on the occasion of her eighty-fifth birthday

\title{
Macrolepiota olivascens, a new species for Poland
}

\author{
JUSTYNA JAWORSKA \\ Department of Botany, Institute of Biology, Jan Kochanowski University \\ Świętokrzyska 15, PL-25-406 Kielce
}

Jaworska J.: Macrolepiota olivascens, a new species for Poland. Acta Mycol. 45 (1): 67-72, 2010.

The article presents a new for Poland species of fungi, Macrolepiota olivascens M. M. Moser \& Singer, found in Milechowy reserve near Chęciny in the western part of the Góry Świętokrzyskie Mountains. Morphological characters of the specimens are described and illustrated in the paper.

Key words: distribution, macrofungi, Milechowy reserve, Góry Świętokrzyskie Mts

\section{INTRODUCTION}

The genus Macrolepiota Singer (Agaricaceae, Agaricales, Basidiomycota) is represented in Europe by 17 species (Horak 2005); in Poland, until now, 6 species of this genus was found (Wojewoda 2003). Differences between particular species concern among others the fruit-bodies morphology, including the size of fruit-body, the occurrence and colour of scales on the cap and the stipe, the structure of the ring, as well as the microscopic features. Differences concern also the occupied habitats. As a result of molecular studies (Vellinga et al. 2003) the genus Macrolepiota turned out to be heterogenic and was divided into two genera Macrolepiota and Chlorophyllum Massee. Among the species listed from Poland to the genus Chlorophyllum only Macrolepiota rachodes was included, whereas M. procera, M. mastoidea, M. konradii and M. excoriata was included in the genus Macrolepiota. The above authors moved Macrolepiota nympharum to the genus Leucoagaricus.

Recently, Macrolepiota olivascens was found in the Milechowy reserve near Chęciny in the western part of the Góry Świętokrzyskie Mountains representing the first finding of this species in Poland. 


\section{MATERIAL AND METHODS}

The fruit-bodies were observed and collected in the field, dried in the laboratory conditions and examined by light microscopy. Measurements of cheilocystidia, basidia and hyphae were done by the eyepiece micrometer.

The collected specimens are deposited in the Fungarium of the Department of Botany, Institute of Biology, Jan Kochanowski University, Kielce (KTC 4191, 4192, 4293).

In order to illustrate the floristic composition, and existing phytosociological conditions of the habitat, in which Macrolepiota olivascens was found, one BraunBlanquet survey was performed. Vascular plants nomenclature is according to Mirek et al. (2002), and mosses according to Ochyra et al. (2003).

\section{DESCRIPTION OF THE SPECIES}

\section{Macrolepiota olivascens M. M. Moser \& Singer}

Schweiz. Z. Pilzk. 39: 154. (1961).

Figs $1-3$

The cap of the mature fruit-body when fresh can reach $125-215 \mathrm{~mm}$ of diameter. The young cap is closed and has oval shape; later becomes convex; the mature cap is plano-spread with a small, rounded umbo. The surface is covered with clearly visible on bright background, brownish tile like arranged scales. The surface in the middle is smooth. The edge of cap is slightly tomentous. The hymenophore is composed of the lamellae, and lamellulas. The lamellae are crowded, bulging out and free. They are white, white-brownish, with a tendency to become pale rosy in colour. The cap, and lamellae when bruised or damaged after a while changed the colour to bright green, olivaceous or grey-olivaceous (characteristic feature for this species, Fig. 1).

The stipe is slim, cylindrical, empty inside, tuberous at the base, $175-420 \mathrm{~mm}$ high and $10 \mathrm{~mm}$ wide. The base can reach the diameter up to $40 \mathrm{~mm}$. The stipe is the same colour as the cap - on the white background there are very small brownish scales, on the surface of stipe characteristic brownish zigzag pattern often occurs. The remnants of complete velum make on the stem a double ring, which is relatively stable, and it exists for a long period of time. This ring is not attached to the stipe, and it can be moved along the stipe. The flesh when fresh is always white, only at the edges of the canals made by Diptera larvae, may be discoloured to bright red or brunneous-red. In the cap the flesh is carneous, whereas in the stipe fibrillous, lignified. The taste and smell are not too strong, similar to those of Macrolepiota procera. The taste is mild and pleasant, the smell is delicate.

The basidia are club-shaped, tetrasporic, 33-47 × 13-15.2 $\mu \mathrm{m}$. Cheilocystidia are club-shaped, very numerous. They are colourless, not projecting, smooth, thinwalled, 14-44 $\times$ 9-13.7 $\mu \mathrm{m}$. Pleurocystidia are absent. Spores are ellipsoid in shape, colourless, pseudoamyloid, and smooth, 12.8-16.9 (-18.2) × 8.8-10.8 $\mu \mathrm{m}$. The germ pore is clearly seen (Fig. 2).

Deposit of the spores when fresh is pale-rosy in colour, whereas when dry (dehydrated) acquires champagne colour. 


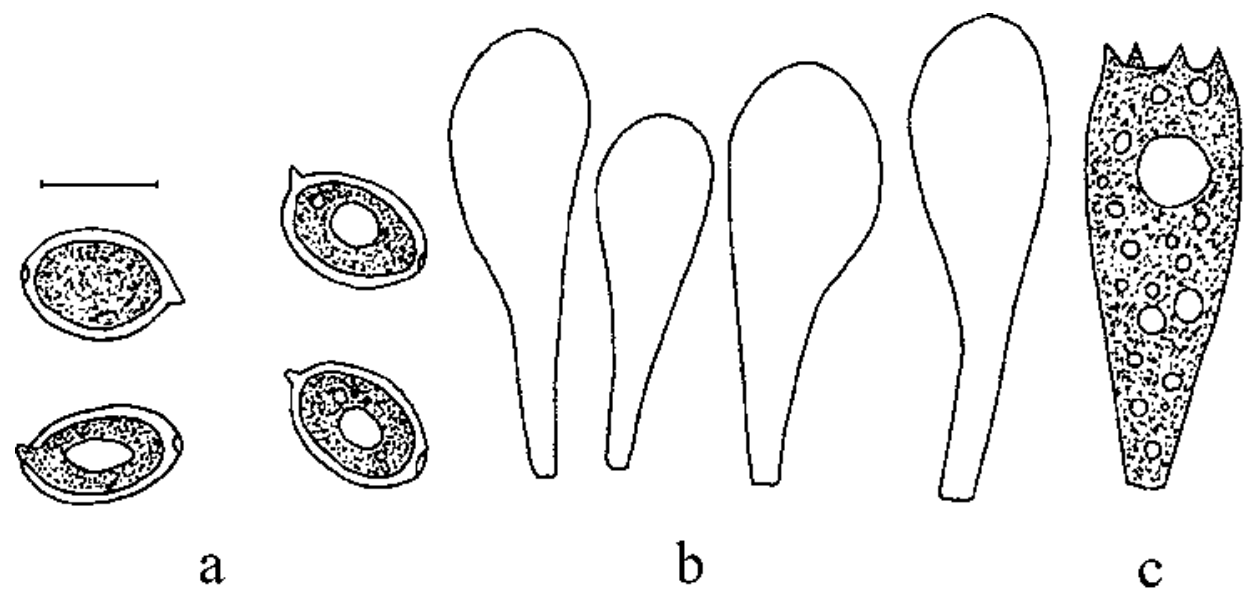

Fig. 2. Macrolepiota olivascens: $\mathrm{a}$ - spores, $\mathrm{b}$ - cheilocystidia, $\mathrm{c}-$ basidium. Scale bar $=10 \mu \mathrm{m}$.

The cells of pileipellis, and stipitipellis are elongated, cylindrical and thin-walled. These cells under the microscope are colourless, and are parallel to each other (they are palisade like). The measurements, and appearance of these cells are similar to those of Macrolepiota procera (Fig. 3). The pileipellis hyphae are made of several cells. The single cells of hyphae measured 38-93 $\times 7.5-11.5 \mu \mathrm{m}$.

Notes. The size, and shapes of basidia, and cheilocystidia in specimens of $M a$ crolepiota olivascens found in Poland are congruent with descriptions given in the literature. (Moser 1983; Candusso, Lazoni 1990; Horak 2005). The spore measurements according to various authors are: (11-) 12-14 × 8.5-10 $\mu \mathrm{m}$ (Moser 1983), 11.5-

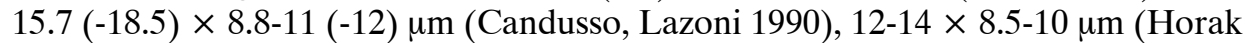
2005). The spores of the fruit-bodies found in Milechowy reserve measured: $12.8-$ $16.9(-18.2) \times 8.8-10.8 \mu \mathrm{m}$, and they are close to the measurements given by the above mentioned authors, particularly Candusso and Lazoni (1990).

Macrolepiota olivascens displays high similarity to Macrolepiota procera. These similarities concern, among others, the structure, and appearance of the fruit-bodies. Both species produce large fruit-bodies, and the surface of their caps is covered with distinct tile like arranged scales (Tab. 1). They occupy similar habitats - coniferous forests, and brushwoods.

SPECIMENS EXAMINED: [ATPOL Ee-72] Poland, Góry Świętokrzyskie Mountains, Chęciny District: Milechowy reserve, near Chęciny, 21.07.2007, leg. J. Jaworska, KTC 4191, 4192, 4293.

DISTRIBUTION AND HABITAT. Macrolepiota olivascens is a rare species. It is known in Europe only from several countries. This species was noted in southern Germany (Krieglsteiner 1991), Austrian Alps (Moser 1983), Czech Republic, Hungary (Candusso, Lazoni 1990), Italy (Narducci, Petrucci 1995), Slovenia (Poler 2006), Sweden (Knudsen, Vesterholt 2008), and Turkey (Kaya 2006). In all these countries this species is rare (Horak 2005). In Austria only three stands of Macrolepiota olivascens are known, in Slovenia - known five stands (Boletus Informaticus 2009). In Turkey its fruit-bodies were found in Anatolia, about $1200 \mathrm{~m}$ above sea level, in Pinus forest. Whereas according to Horak (2005) it is the subalpine species. 


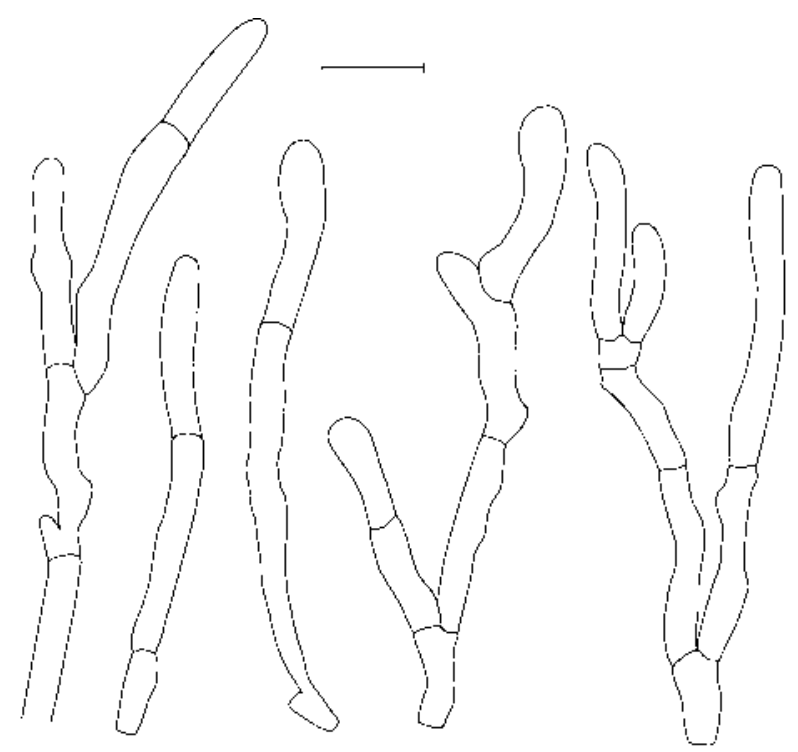

d
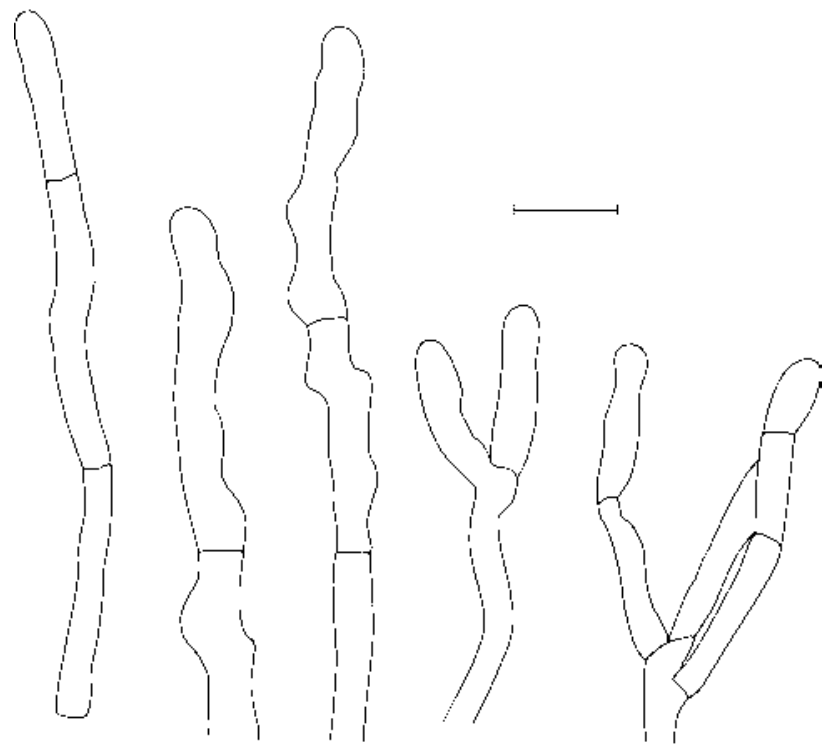

b

Fig. 3. Macrolepiota olivascens: a - hyphae of pileipellis, b - hyphae of stipitipellis. Scale bar $=20 \mu \mathrm{m}$.

This fungus produces the fruit-bodies growing solitary or in groups on the soil mostly in coniferous forests, as well as in other habitats, but in the vicinity of coniferous trees such as pine and larch. The fruit-bodies occur in the summer and autumn.

In July 2007 for the first time the occurrence of this species was confirmed in Milechowy reserve near Chęciny in the western part of the Świętokrzyskie Mountains 

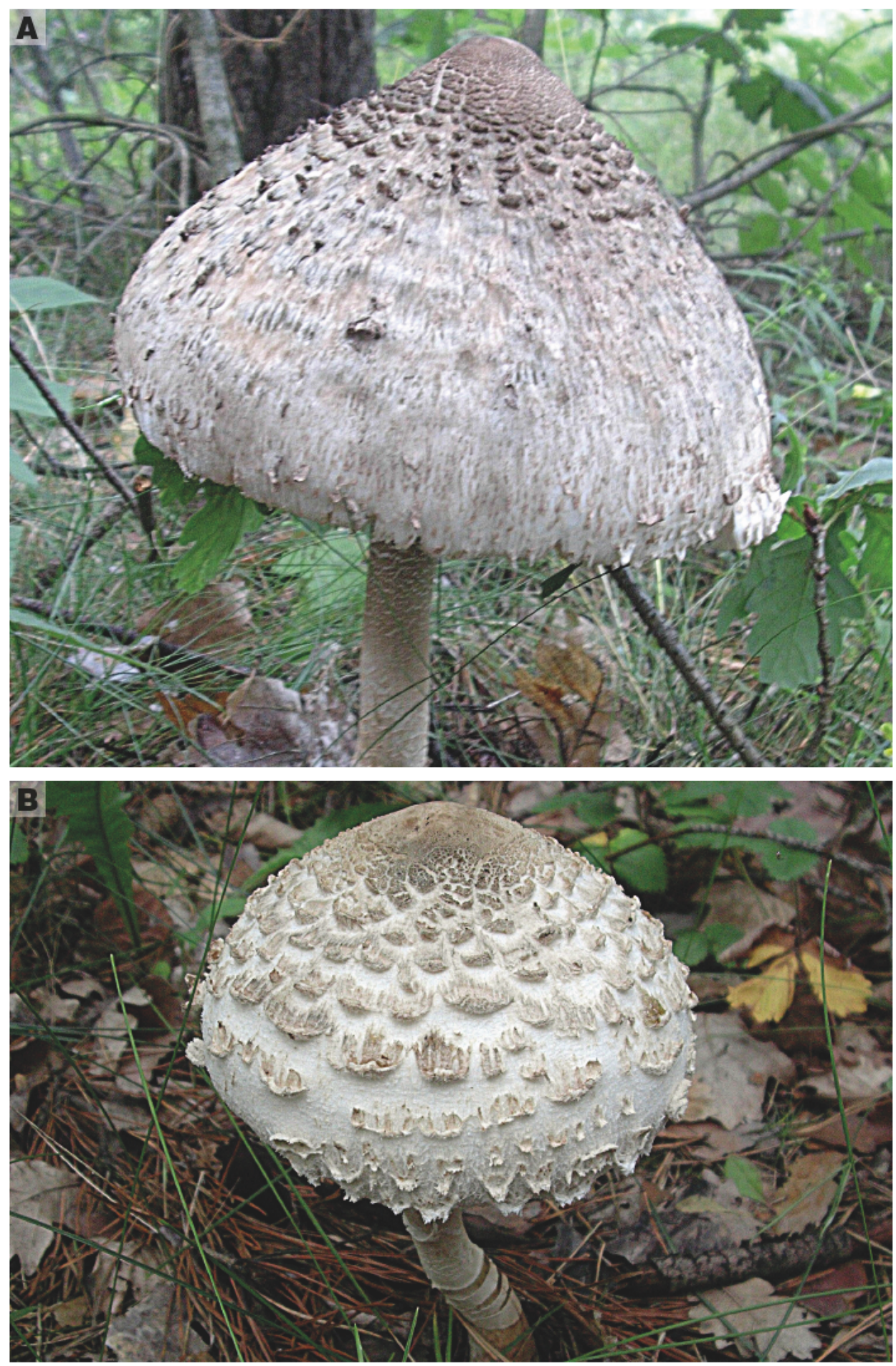

Fig. 1: A, B - Fruit-bodies of Macrolepiota olivascens. 

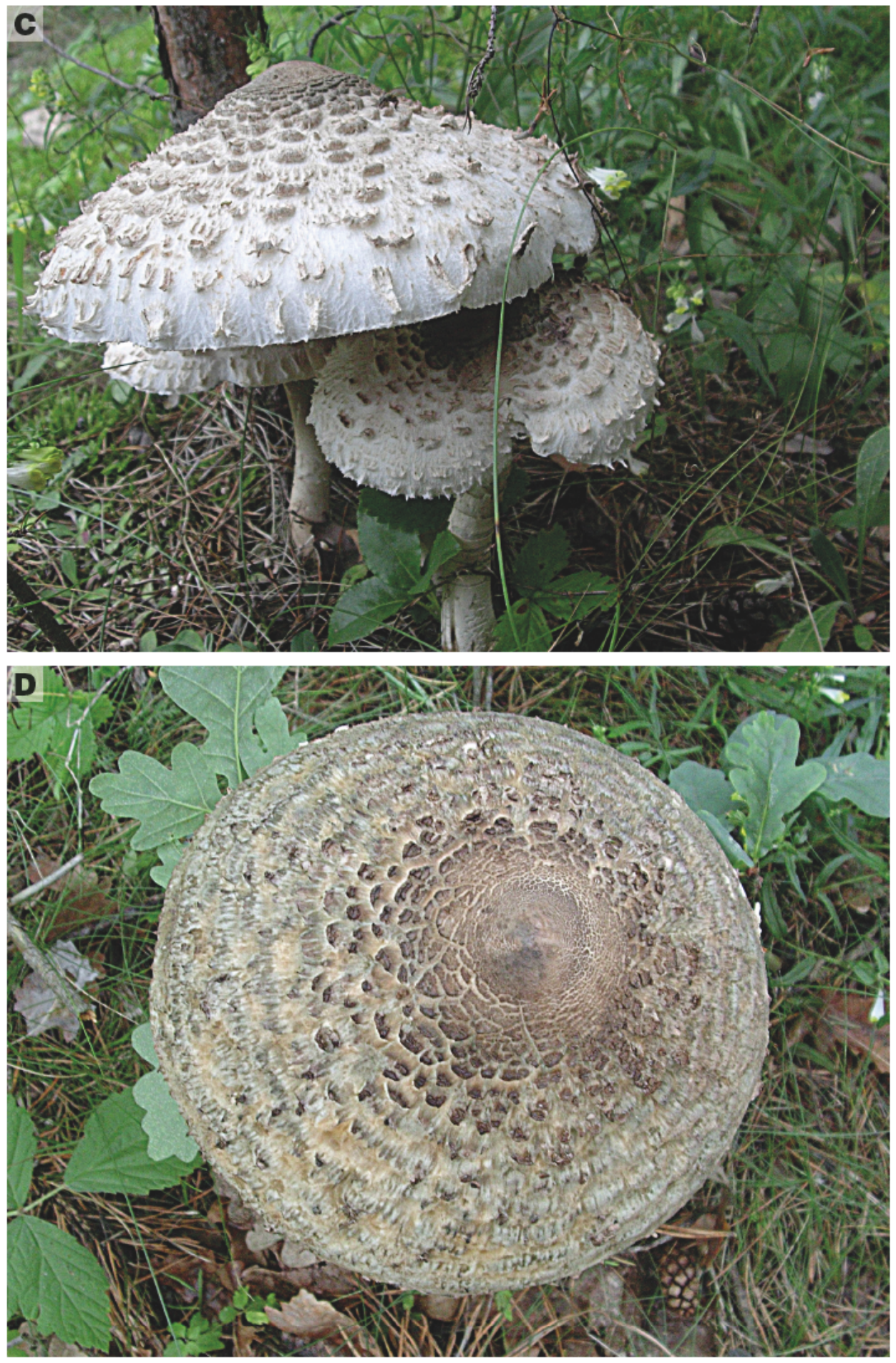

Fig. 1: C, D - Fruit-bodies of Macrolepiota olivascens (continued). 
Table 1

Comparison of selected features of Macrolepiota olivascens and M.procera

\begin{tabular}{|c|c|c|}
\hline Selected features & Macrolepiota olivascens & Macrolepiota procera \\
\hline Spores & $\begin{array}{l}\text { elipsoidal, } \\
11.5-15.7(-18.5) \times 8.8-11(-12) \mu \mathrm{m}\end{array}$ & $\begin{array}{l}\text { elipsoidal, } \\
13-17(-23) \times(8.5-) 9-10.5(-12) \mu \mathrm{m}\end{array}$ \\
\hline Basidia & $\begin{array}{l}\text { club-shaped, } \\
\text { tetrasporic, } \\
\text { 33-47x13-15.2 } \mu \mathrm{m}\end{array}$ & $\begin{array}{l}\text { club-shaped, } \\
\text { most tetrasporic, but also bisporic } \\
(30-) 35-48(-55) \times 13-17(-20) \mu \mathrm{m}\end{array}$ \\
\hline Cheilocystidia & $14-44 \times 9-13.7 \mu \mathrm{m}$ & $20-50 \times 8-16(-20) \mu \mathrm{m}$ \\
\hline Flesh & white, constant & white, constant \\
\hline Surface of stipe & $\begin{array}{l}\text { covered with brownish small scales, } \\
\text { making characteristic brownish } \\
\text { zigzag pattern }\end{array}$ & $\begin{array}{l}\text { covered with brownish small scales, } \\
\text { making characteristic brownish } \\
\text { zigzag pattern }\end{array}$ \\
\hline $\begin{array}{l}\text { Reaction for damages } \\
\text { or bruising }\end{array}$ & $\begin{array}{l}\text { surface of cap, and lamellae in } \\
\text { place of bruising acquire green- } \\
\text { olivaceous or grey-olivaceous }\end{array}$ & colouring does not change \\
\hline Habitat & $\begin{array}{l}\text { coniferous forests, brushwood of } \\
\text { coniferous trees }\end{array}$ & $\begin{array}{l}\text { coniferous forests, meadows, parks, } \\
\text { clearings }\end{array}$ \\
\hline
\end{tabular}

$230 \mathrm{~m}$ above sea level (Chęciny District) (Fig. 4). Several fruit-bodies were found at the perifery of the reserve in the young pine plantings, and brushwood including Pinus sylvestris. Soil of these stands is sandy, developed on the lime substratum.

The floristic composition of the plant habitat, in which the fruit-bodies were found is as follow: density of tree layer $65 \%$, density of shrub layer $15 \%$, cover of herb layer $40 \%$, cover of moss layer $30 \%$.

Forest stand consists only of Pinus sylvestris 4.4. In the shrub layer occur: Lonicera xylosteum 1.1, Quercus petraea 1.1, Juniperus communis 1.1, Carpinus betulus +. In the ground cover mainly occur: Festuca rubra 3.3, Fragaria vesca 1.2, Hieracium pilosella +.2 , Thymus serpyllum 1.2, Chimaphila umbellata 1.1, Melampyrum pratense 2.2, Vaccinium myrtillus +.2 , Galium mollugo +.2 , Veronica officinalis 1.1 . In the moss layer mostly occur: Entodon schreberi 3.3, and Hylocomium splendens 3.3.

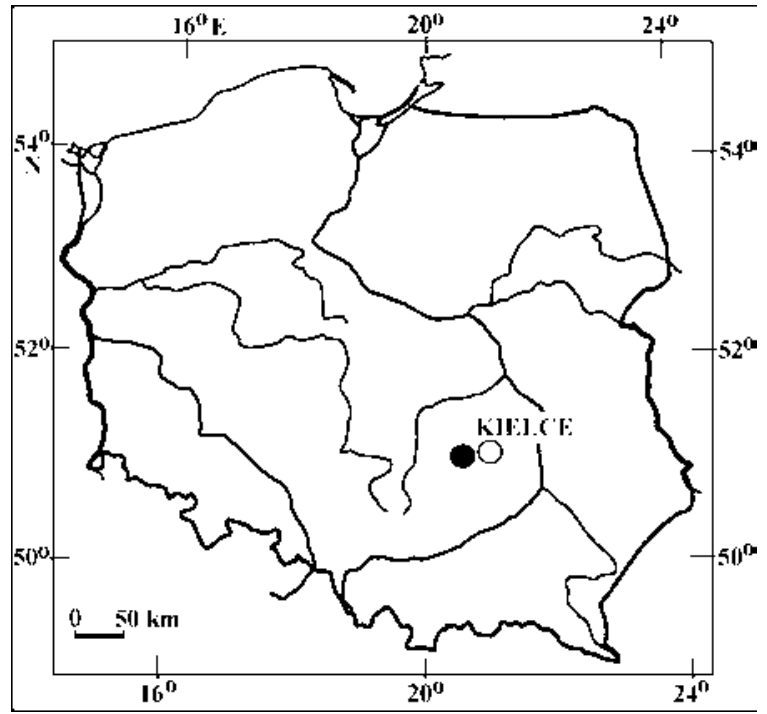

Fig. 4. Locality of Macrolepiota olivascens in Poland. 
After the first finding of Macrolepiota olivascens in July 2007 the species was not found again in that year, and not in 2008, despite the regular observations.

Acknowledgements. I am very grateful to Prof. Janusz Łuszczyński, and Prof. Andrzej Massalski for helpful discussion, and comments on the manuscript.

\section{REFERENCES}

Boletus Informaticus. 2009. http://data.gbif.org/species/15051190.

Candusso M., Lazoni G. 1990. Lepiota s.1. Fungi Europaei. Libreria editrice Giovanna Biella. Sarono, 743 pp.

Horak E. 2005. Röhrlinge und Blätterpilze in Europe. Elsevier GmbH, Spektrum Akademischer Verlag. München, p. I-XVII + 1-555.

Kaya A. 2006. Macrofungi from Anfrin (Kahramanmaras) District. Turk. J. Bot. 30: 85-93.

Knudsen H., Vesterholt J. (eds). 2008. Funga Nordica: Agaricoid, boletoid and cyphelloid genera. Nordsvamp, Copenhagen, 965 pp.

Krieglsteiner G. J. 1991. Verbreitungsatlas der Großpilze Deutschlands (West). 1. Ständerpize. Teil B: Blätterpilze. Verlag E. Eugen, Stuttgart: 421-1016.

Mirek Z., Piękoś-Mirkowa H., Zając A., Zając M. 2002. Flowering plants and pteridophytes of Poland - a checklist. (In:) Z. Mirek (ed.). Biodiversity of Poland 1. W. Szafer Institute of Botany, Polish Academy of Sciences. Kraków, XXX pp.

Moser M. 1983. Die Röhlinge und Blätterpilze (Polyporales, Boletales, Agaricales, Russulales). Kleine Kryptogamenflora, IIb/2, Basidiomycetes, 2. VEB G. Fischer Verl., Jena, 532 pp.

Narducci R., Petrucci P. 1995. Macromiceti reperiti in provincia di Lucca negli anni 1985-1994 con le indicazioni dei luoghi e degli ambient di raccolta. (In:) P.E. Tomei, L. Zocco Pisana (eds). Contributo alla conoscenza dei macromiceti che crescono nella provincial di Lucca. Comunità Montana della Garfagnana, Orto Botanico Pana di Corfino. Tipografia Editrice Pisana. Pisa, 151 pp.

Ochyra R., Żarnowiec J , Bednarek-Ochyra H. 2003. Census Catalogue of Polish Mosses. In: Z. Mirek (ed.). Biodiversity of Poland 3. W. Szafer Institute of Botany, Polish Academy of Sciences. Kraków, 372 pp.

Poler A. 2006. Mikološka zveza Slovenije [www.gobe-zveza.si/razstave/20060908.htm]

Vellinga E. C., Kok R. P. J., Bruns T. D. 2003. Phylogeny and taxonomy of Macrolepiota (Agaricaceae). Mycologia 95 (3): 442-456.

Wojewoda W. 2003. Checklist of Polish larger Basidiomycetes. (In:) Z. Mirek (ed.). Biodiversity of Poland 7. W. Szafer Institute of Botany, Polish Academy of Sciences. Kraków, 812 pp.

\section{Macrolepiota olivascens, nowy gatunek dla Polski}

\section{Streszczenie}

Macrolepiota olivascens M. M. Moser \& Singer jest nowym gatunkiem dla Polski, którego stanowisko zostało znalezione w rezerwacie Milechowy koło Chęcin, w zachodniej części Gór Świętokrzyskich (Okręg Chęciński). Jest gatunkiem rzadkim występującym w lasach iglastych, a także w innych zbiorowiskach leśnych z udziałem drzew iglastych. Macrolepiota olivascens wykazuje duże podobieństwo morfologiczne do Macrolepiota procera. Cechą odróżniającą te dwa gatunki jest zielenienie uszkodzonych miejsc na kapeluszu i blaszkach owocników Macrolepiota olivascens.

Macrolepiota olivascens w Europie znany jest zaledwie w kilku krajach. Zanotowano jego występowanie w Południowych Niemczech, Alpach Austriackich, Republice Czeskiej, na Węgrzech, we Włoszech oraz w Słowenii, Szwecji i Turcji. Wszędzie jest gatunkiem rzadko spotykanym. 